\title{
Pengasuhan Orangtua dan Kepercayaan Diri terhadap Kemandirian Belajar Siswa SMA dengan Kecerdasan Emosional sebagai Variabel Intervening
}

\author{
Vivit Kartika ${ }^{1}$, Rini Sugiarti ${ }^{2}$ \\ 1,2Fakultas Psikologi, Universitas Semarang \\ Jl. Arteri Soekarno Hatta, Tlogosari Kulon, Kota Semarang, Jawa Tengah 59160 \\ 1vivitvinka@gmail.com, 2rinisugiartipsikologi@usm.ac.id
}

Article History:

Received

2021-10-25

Review

2021-12-11

Revised

2021-12-27

Accepted

2021-12-27

Published

2021-12-28
Abstract. This study aims to : 1) empirically examine the effect of parenting on independent learning in high school students. 2) empirically test the effect of self-confidence on independent learning. 3 ) empirically test the effect of emotional intelligence on independent learning. 4) empirically test the effect of parenting on independent learning through emotional intelligence. 5) empirically test the effect of self-confidence on independent learning through emotional intelligence. Subjects in this study amounted to 105 students. This study uses a population study technique. The research data was collected using four scales, namely the learning independence scale, the emotional intelligence scale, the parenting scale, and the selfconfidence scale. Data analysis used path analysis using the SmartPLS 3.0 program. The results showed 1) parental care had a positive and significant effect on learning independence in high school students with $p=0.022$ where $p<0.05 .2$ ) self-confidence has a positive and significant effect on learning independence in high school students with $\mathrm{p}=0.035$ where $\mathrm{p}<0.05$. 3) emotional intelligence has a positive and significant effect on learning independence in high school students with $p=0.001$ where $p<0.05$. 4) parental care has an effect on learning independence in high school students through emotional intelligence with $p=0.037$ where $p<0.05$. 5) selfconfidence affects learning independence in high school students through emotional intelligence with $\mathrm{p}=0.031$ where $\mathrm{p}<0.05$.

Keywords: learning independence, emotional intelligence, parenting, and self-confidence

Abstrak. Penelitian ini bertujuan untuk 1) menguji secara empiris pengaruh pengasuhan orang tua terhadap kemandirian belajar pada siswa SMA. 2) menguji secara empiris pengaruh kepercayaan diri terhadap kemandirian belajar. 3) menguji secara empiris pengaruh kecerdasan emosional terhadap kemandirian belajar. 4) menguji secara empiris pengaruh pengasuhan orang tua terhadap kemandirian belajar melalui kecerdasan emosional. 5) menguji secara empiris pengaruh kepercayaan diri terhadap kemandirian belajar melalui kecerdasan emosional. Subjek dalam penelitian ini berjumlah 105 siswa. Penelitian ini menggunakan teknik studi populasi. Data penelitian dikumpulkan dengan menggunakan empat skala yaitu skala kemandirian belajar, skala kecerdasan emosional, skala pengasuhan orang tua, dan skala kepercayaan diri. Analisis data menggunakan analisis jalur dengan menggunakan program SmartPLS 3.0. Hasil penelitian menunjukkan 1) pengasuhan orang 
tua berpengaruh positif dan signifikan terhadap kemandirian belajar pada siswa SMA dengan $p=0.022$ dimana $p<0,05$. 2) kepercayaan diri berpengaruh positif dan signifikan terhadap kemandirian belajar pada siswa SMA dengan $\mathrm{p}=0.035$ dimana $\mathrm{p}<0.05$. 3)kecerdasan emosional berpengaruh positif dan signifikan terhadap kemandirian belajar pada siswa SMA dengan $\mathrm{p}=0.001$ dimana $\mathrm{p}<0.05$. 4) pengasuhan orang tua berpengaruh terhadap kemandirian belajar pada siswa SMA melalui kecerdasan emosional dengan $\mathrm{p}=0.037$ dimana $\mathrm{p}<0,05$. 5) kepercayaan diri berpengaruh terhadap kemandirian belajar pada siswa SMA melalui kecerdasan emosional dengan $\mathrm{p}=0.031$ dimana $\mathrm{p}<0,05$.

Kata kunci: kemandirian belajar, kecerdasan emosional, pengasuhan orang tua, dan kepercayaan diri

\section{Pendahuluan}

Sekolah adalah lembaga formal yang bertujuan untuk memberikan pengajaran dan mendidik para murid-murid melalui para pendidik atau guru. Pendidikan formal melewati jenjang SD, SMP, dan SMA, dalam kegiatan belajar-mengajar di sekolah harus didukung oleh sarana dan prasarana serta berbagai aturan/ peraturan yang telah dirancang dan ditetapkan oleh pemerintah.

Menurut Papalia (Papalia, 2009) masa remaja adalah saat meningkatnya perbedaan di antara kebanyakan remeja, yang menuju ke masa dewasa yang memuaskan dan produktif . Remaja sebagai seorang siswa/pelajar tergolong masa transisi (trantition stage) yaitu masa peralihan dari masa anak-anak menuju masa dewasa muda. Sebagian remaja mengalami masalah dalam menghadapi berbagai perubahan yang terjadi secara bersamaan dan membutuhkan bantuan dalam mengatasi bahaya saat menjalani masa ini.

Menurut Maslow (Ramadhan dan Ipah, 2017) kemandirian merupakan salah satu kebutuhan meta yaitu kebutuhan untuk mengaktualisasikan diri, tidak tergantung dan mampu menentukan diri sendiri. Pentingnya perkembangan kemandirian dikemukakan pula oleh Steinberg (Ramadhan dan Ipah, 2017) menafsirkan kemandirian sebagai kemampuan menguasai diri. Kemampuan menguasai diri ini bukan hanya diperlukan oleh orang dewasa, kemampuan tersebut perlu dikembangkan oleh remaja agar mereka tidak selalu bergantung kepada orang tua atau orang dewasa lainnya, serta mampu mengambil keputusan sendiri dan konsisten terhadap keputusan tersebut.

Situasi kehidupan saat ini sudah semakin kompleks yang ditunjang oleh perkembangan teknologi digital dan generasi 4.0 yang semakin canggih. Pernyataan ini didukung dengan penelitian dari Yuliati \& Dudu (2020) yang mengungkapkan bahwa kemandirian belajar merupakan salah satu aspek penting yang harus dimiliki oleh siswa 
demi tercapainya kompetensi secara optimal, namun nyatanya kemandirian dalam belajar masih kurang begitu baik, maka pendidik sudah seharusnya melaksanakan pembelajaran yang dapat memfasilitasi terbentuknya kemandirian belajar. Kemandirian dapat membantu siswa menciptakan kebiasaan belajar yang lebih baik dan memperkuat kemampuan belajarnya. Kemandirian dapat mendorong siswa untuk meningkatkan hasil akademik serta mengevaluasi akademis siswa, sehingga kemandirian belajar saat ini penting untuk proses pembelajaran. Kegiatan belajar mengajar akan sulit berjalan ketika siswa tidak memiliki kemandirian dalam belajar, artinya siswa perlu memiliki dorongan untuk belajar.

Berdasarkan hasil wawancara dengan guru di SMA Negeri 2 Mranggen, berbagai upaya dilakukan untuk meningkatkan kemandirian siswa di sekolah, bekerjasama dengan berbagai perangkat sekolah dari guru BK dan juga orang tua. Guru BK mengatakan jika terdapat murid yang tdak dapat mengikuti pelajaran dengan baik maka orang tua akan dipanggil dan akan dikomunikasikan solusinya. Akan tetapi dalam kenyataannya masih terdapat perilaku tidak mandiri dalam mengerjakan tugas-tugas sekolah, maupun saat mengikuti pelajaran. Dalam wawancara guru mengatakan misal kelas dimulai jam 8, maka guru harus mengingatkan siswa terlebih dahulu untuk on-camera agar segera mempersiapkan, supaya yang mengikuti pelajaran nanti lebih banyak.

Ketidakmandirian belajar siswa juga tampak saat proses pengerjaan tugas. Guru mengungkapkan ketika siswa diberikan tugas maka akan dikerjakan secara mencontek, hanya 20\% yang mengerjakan secara mandiri, sehingga dalam satu kelas terdapat jawaban yang mirip. Sumber mengerjakan hanya satu atau dua orang kemudian jawaban tersebut dibagikan pada teman-teman yang lain. Tugas tersebut tidak hanya dibagikan pada teman sekelas, namun juga kelas lain. Begitu pula saat waktu pengumpulan tugas, terlihat banyak siswa yang terlambat saat pengumpulan tugas, guru mengatakan setidaknya 25-30 siswa saja yang mengumpulkan tepat waktu, sehingga guru terkadang mengingatkan atau menegur terlebih dahulu siswa yang terlambat dalam pengumpulan tersebut.

Siswa di sekolah tersebut banyak yang mengikuti les di lembaga bimbingan belajar maupun dengan guru mata pelajaran, hal ini terungkap saat wawancara siswa yang mengatakan bahwa kebanyakan siswa lebih memilih les privat dengan guru mata pelajaran, karena sesuai dengan yang diberikan waktu di sekolah dan terkadang sudah diberi kisi-kisi saat akan ulangan. Guru juga mengungkapkan jika kemandirian belajar beberapa siswa kurang karena merasa sekolah secara online dimudahkan dalam kenaikan 
kelasnya. Dari hasil wawancara tersebut maka dapat disimpulkan siswa tidak mandiri dalam belajar dan mengerjakan tugas sekolah.

Pengasuhan diyakini merupakan salah satu faktor yang mempengaruhi kemandirian siswa dalam belajar. Furhmann (dalam Asiyah, 2013) menyatakan bahwa kemampuan seseorang untuk mengembangkan kemandirian berkaitan dengan pengalaman mereka bersama keluarganya. Hubungan yang baik antara orang tua-anak akan mendukung seseorang untuk mandiri, sehingga perkembangan individu tidak menghasilkan penolakan atas pengaruh orang tua, justru seseorang akan mencari masukan dari orang tua.

Pengasuhan yang diberikan kepada orang tua menjadikan anak terbentuk dan tercermin dalam kehidupan sehari-hari. Kunci kemandirian sebenarnya ada ditangan orang tua. Kemandirian yang dihasilkan dari kehadiran dan bimbingan orang tua akan menghasilkan kemandirian yang utuh. Untuk dapat mandiri anak membutuhkan kesempatan, dukungan dan dorongan dari keluarga khususnya pola asuh orang tua serta lingkungan sekitarnya (Asiyah, 2013).

Pendapat ini juga didukung penelitian dari Pravitasari (2019) yang menyatakan bahwa pola pengasuhan yang diterapkan orang tua dapat berpengaruh khususnya dalam hal kemandirian serta kelangsungan hidup anak. Pola pengasuhan memegang peranan penting dalam masa pertumbuhan dan perkembangan anak, terutama pada anak yang berusia 3-17 tahun. Pola asuh orang tua yang tepat akan berdampak positif bagi perkembangan dan kemandirian anak, sedangkan pola asuh yang kurang tepat akan berdampak negatif terhadap perkembangan dan kemandirian anak di masa depan.

Kepercayaan diri mempengaruhi kemandirian belajar siswa. Pendapat tersebut didukung oleh pendapat dari Steinberg (Pratiwi \& Hermien, 2016) yang menyebutkan bahwa kemandirian belajar dapat muncul dan berfungsi, apabila individu memiliki kepercayaan diri yang meningkat. Individu yang tidak memiliki tingkat kepercayaan diri yang tinggi, tidak dapat menumbuhkan sikap kemandirian belajar dalam dirinya. Siswa yang percaya diri biasanya mempunyai inisiatif, kreatif dan optimis terhadap masa depan, mampu menyadari kelemahan dan kelebihan diri sendiri, berpikir positif, menganggap semua permasalahan pasti ada jalan keluarnya. Siswa yang tidak percaya diri ditandai dengan sikap-sikap yang cenderung melemahkan semangat hidup, seperti minder, pesimis, dan pasif. Kepercayaan diri mempengaruhi kemandirian siswa dalam mengambil keputusan sendiri tanpa pengaruh dari orang lain, siswa yang mandiri mampu memotivasi 
diri untuk bertahan dari kesulitan yang dihadapi dan dapat menerima kegagalan dengan pikiran yang rasional (Pratiwi \& Hermien, 2016).

Kecerdasan emosional pada masa remaja diperlukan pula sebagai bekal keterampilan emosi dan sosial untuk mengenali, mengolah, dan mengontrol emosi dalam mengatasi berbagai rintangan hidup. Goleman mengutarakan (Desmita, 2009), kecerdasan emosional merujuk pada kemampuan mengenali perasaan kita sendiri dan perasaan orang lain, kemampuan memotivasi diri sendiri, dan kemampuan mengelola emosi dengan baik pada diri sendiri dan dalam hubungan dengan orang lain. Kecerdasan emosi mencakup kemampuan-kemampuan yang berbeda tetapi saling melengkapi dengan kecerdasan akademik ( academic intelligence), yaitu kemampuan-kemampuan kognitif murni yang diukur dengan IQ.

Pengasuhan orang tua menjadi salah satu faktor yang mempengaruhi kecerdasan emosi seorang anak. Pendapat ini didukung oleh pemaparan dari Goleman (Fitriyani, 2015) yang menyebutkan bahwa faktor yang mempengaruhi kecerdasan emosi diantaranya faktor internal yaitu faktor yang timbul dari dalam diri sendiri dan faktor eksternal yaitu faktor yang datang dari luar diri individu dan mempengaruhi individu untuk mengubah sikapnya. Kondisi juga dapat mempengaruhi perkembangan kecerdasan emosi seperti yang disebutkan oleh Hurlock yaitu kondisi kesehatan, suasana rumah, cara mendidik anak, hubungan dengan para anggota keluarga, hubungan dengan teman sebaya, perlindungan yang berlebih-lebihan, aspirasi orang tua, dan bimbingan.

Semakin tinggi pengasuhan orang tua maka semakin tinggi pula kecerdasan emosional. Namun data awal di lapangan yang dikumpulkan peneliti melalui google form dengan mengumpulkan sebanyak 10 orang siswa yang mengisi menunjukkan pengasuhan orang tua yang baik sebanyak $60 \%$ dan sedang sebanyak $40 \%$, sedangkan kecerdasan emosional menunjukkan kategori rendah sebanyak 50\%, sedang $40 \%$ dan tinggi $10 \%$. Hal ini menunjukkan bahwa siswa di sekolah tersebut memiliki pengasuhan orang tua yang tinggi namun memiliki kecerdasan emosional yang rendah.

Penelitian lain juga menyebutkan bahwa Hasil analisis regresi berganda kepercayaan diri berpengaruh signifikan terhadap kecerdasan emosinal. Nilai koefisien regresinya bernilai positif yakni sebesar 0,002 (Apriandi, 2015). Hal tersebut berarti kecerdasan emosional juga berpengaruh pada kepercayaan diri.

Kepercayaan diri merupakan salah satu bentuk dari kecerdasan emosional. Pernyataan ini didukung oleh penelitian dari Karlinawati yang menyatakan bahwa 
kecerdasan emosional memberikan kontribusi dengan rasa percaya diri siswa sebesar $35 \%$ atau dapat disimpulkan rasa percaya diri siswa berhubungan dengan kecerdasan emosional 35\%, sedangkan sisanya $65 \%$ dipengaruhi oleh faktor lain (Karlinawati, 2015).

Kecerdasan emosional berpengaruh terhadap kemandirian belajar siswa. Hal ini dibuktikan dengan penelitian dari Dianah (Afero, 2016) yang menunjukkan bahwa hasil penelitian kecerdasan emosional memiliki pengaruh yang positif dan signifikan terhadap kemandirian belajar siswa. Adapun pengaruh kecerdasan emosional terhadap kemandirian belajar siswa sebesar 21,85\%. Dengan demikian kemandirian belajar siswa dapat ditingkatkan melalui peningkatan kecerdasan emosional. Berdasarkan penelitian lain disimpulkan pula bahwa kecerdasan emosional memberikan kontribusi yang signifikan terhadap kemandirian siswa (Bayu \& Anita dalam Afero, 2016) dan menurut Bar-On, kompetensi kecerdasan emosional dan kemandirian digambarkan sebagai kemampuan individu untuk menjadi mandiri.

Pendapat tersebut didukung oleh penelitian dari Dianah (Dianah, 2017) yang menyatakan bahwa kecerdasan emosional berpengaruh positif dan signifikan terhadap kemandirian belajar siswa. Semakin baik kualitas kecerdasan emosional, maka akan semakin meningkat kemandirian belajar siswa. Variabel kecerdasan emosional memiliki pengaruh lebih besar terhadap kemandirian belajar.

Kemandirian belajar adalah salah satu kunci keberhasilan siswa di sekolah. Tentunya tidak mudah karena membutuhkan kerjasama pengasuhan orang tua, kepercayaan diri, dan kecerdasan emosional sebagai factor yang mempengaruhi. Dalam teori mengatakan bahwa adanya pengasuhan orang tua dan kepercayaan diri akan meningkatkan kecerdasan emosional yang nantinya akan mempengaruhi kemandirian belajar siswa menjadi lebih baik. Namun pada kenyataannya hasil dilapangan bertolak belakang dengan teori yang sudah ada. Pengasuhan orang tua yang baik dan kepercayaan diri meningkatkan kecerdasan emosional, namun mengapa kemandirian belajar siswa masih rendah.

Sesuai dengan rumusan masalah yang telah diajukan, maka tujuan yang ingin dicapai dalam penelitian ini adalah : 1) Menguji secara empiris pengaruh pengasuhan orang tua terhadap kemandirian belajar pada siswa SMA. 2) Menguji secara empiris pengaruh kepercayaan diri terhadap kemandirian belajar pada siswa SMA. 3) Menguji secara empiris pengaruh kecerdasan emosional terhadap kemandirian belajar pada siswa SMA. 4) Menguji secara empiris pengaruh pengasuhan orang tua terhadap kemandirian belajar melalui kecerdasan emosional pada siswa SMA. 5) Menguji secara empiris 
pengaruh kepercayaan diri terhadap kemandirian belajar melalui kecerdasan emosional pada siswa SMA.

\section{Metode}

Peneitian dilakukan pada siswa SMA Negeri 2 Mranggen Kelas XI yang berjumlah 105 siswa . pada penelitian ini terdapat 4 variabel, yaitu : Kemandirian Belajar (Y), Kecerdasan Emosional (Z), Pengasuhan Orang Tua (X1), dan Kepercayaan Diri (X2).

Teknik Pengumpulan data dalam penelitian ini menggunakan metode angket yang berupa kuisioner. Instrumen kuisioner tersebut masing-masing digunakan untuk mengukur kemandirian belajar, kecerdasan emosional, pola asuh orang tua dan kepercayaan diri. Instrumen berisi pernyataan-pernyataan mengenai variabel yang diteliti.

Teknik analisis data yang digunakan dengan menggunakan metode analisis jalur (Path Analysis) dengan program SmartPLS. Analisis jalur merupakan perluasan dari analisis regresi linier. Analsisi jalur adalah penggunaan analisis regresi untuk menaksir hubungan kausalitas antar variabel (model casual) yang telah ditetapkan sebelumnya berdasakan teori (Ghozali, 2018).

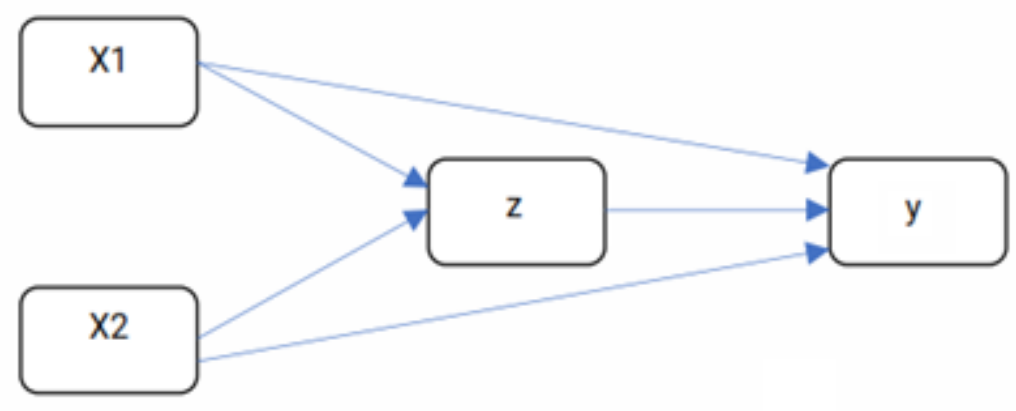

Hasil

\section{Uji validitas dan reliabilitas hasil penelitian}

\section{a. Uji Validitas}

Pengujian validitas item dengan menggunakan bantuan program SmartPLS 3.0. Langkah pertama yang dilakukan dalam pengujian SEM PLS uji validitas adalah mengukur model dengan kriteria nilai outer loading pada masing - masing variabel yang diteliti. Dengan nilai patokan loading ideal yang diharapkan adalah $>0,7$. Dari hasil pengukuran ada beberapa butir soal yang gugur pada masing-masing variabel. Butir soal yang mempunyai nilai loading $>0,7$ dinyatakan valid dan dipakai untuk pengukuran selanjutnya. Sedangkan butir soal yang memiliki nilai loading $<0,5$ dikeluarkan dari model. 
Setelah itu model disusun kembali dan diukur dengan menggunakan parameter outer loading dan AVE (Average Variance Extraced). Ukuran refleksif individual dikatakan berkorelasi jika nilai lebih dari 07 dengan konstruk yang ingin diukur (Ghozali \& Latan, 2015). Dari hasil analisis model pengukuran terdapat beberapa variabel yang nilai faktor loadingnya $<0,70$. Sehingga untuk memenuhi rule of thumb nya, maka variabel manifest yang nilainya $<0,70$ harus dikeluarkan dari model.

Penyusunan skala kemandirian belajar yang semula berjumlah 24 item tidak terdapat item yang gugur. Koefisien validitas item berkisar antara 0,755 sampai 0,853. Penyusunan skala kecerdasan emosional yang semula berjumlah 30 item, terdapat 2 item gugur sehingga tersisa 28 item yang valid. Koefisien validitas item berkisar antara 0,711 sampai 0,868 . Penyusunan skala pengasuhan orang tua yang semula berjumlah 24 item, terdapat 5 item gugur sehingga tersisa 19 item yang valid. Koefisien validitas item berkisar antara 0,720 sampai 0,870. Penyusunan skala kepercayaan diri yang semula berjumlah 24 item, terdapat 3 item gugur sehingga tersisa 21 item yang valid. Koefisien validitas item berkisar antara 0,718 sampai 0,866 .

\section{b. Uji Reliabilitas}

Uji reliabilitas dilakukan untuk membuktikan akurasi, konsistensi, dan ketepatan instrumen dalam mengukur suatu konstruk. Dalam PLS-SEM dengan menggunakan SmartPLS, untuk mengukur reliabilitas suatu konstruk dapat dilakukan dengan dua cara, yaitu dengan Cronbach's Alpha dan Composive reliability. Namun, penggunaan Cronbach's Alpha untuk menguji reliabilitas suatu konstruk akan memberikan nilai yang lebih rendah (under estimate) sehingga lebih disarankan untuk menggunakan Composive Reliability.

Tabel 1. Uji Reliabilitas

\begin{tabular}{clcccc}
\hline No. & Variabel & $\begin{array}{c}\text { Cronbach's } \\
\text { Alpha }\end{array}$ & Rho_A & $\begin{array}{c}\text { Composite } \\
\text { Reliability }\end{array}$ & $\begin{array}{c}\text { Average Variance } \\
\text { Extracted (AVE) }\end{array}$ \\
\hline 1 & Kecerdasan Emosional & 0.960 & 0.962 & 0.963 & 0.595 \\
\hline 2 & Kemandirian Belajar & 0.975 & 0.976 & 0.977 & 0.660 \\
\hline 3 & Kepercayaan Diri & 0.977 & 0.979 & 0.979 & 0.631 \\
\hline 4 & Pengasuhan Orang Tua & 0.969 & 0.971 & 0.971 & 0.641 \\
\hline
\end{tabular}

Dari tabel diatas dapat dilihat bahwa nilai semua variabel dalam pengujian reliabilitas baik menggunakan Cronbach's Alpha ataupun Composite reliability nilainya > 0.70, dan pengujian validitas dengan menggunakan AVE (Average Variance Extracted) nilainya $>0.50$. Oleh karena itu, dapat disimpulkan bahwa variabel - variabel yang diujikan valid dan juga reliabel, sehingga dapat dilanjutkan untuk menguji model struktural. 
Philanthropy Journal of Psychology

Vol 5 Nomor 2 (2021), 377-390

ISSN 2580-6076 (Print), ISSN 2580-8532 (Online)

\section{Analisis model struktural (Inner Model)}

Evaluasi model struktural atau inner model bertujuan untuk memprediksi hubungan antar variabel laten. Model struktural dievaluasi dengan melihat besarnya presentase variance yang dijelaskan yaitu dengan melihat nilai $R$-Square untuk konstruk laten endogen, dan AVE untuk predictivenness dengan menggunakan prosedur resampling seperti jackkniffing dan bootstrapping untuk memperoleh stabilitas dari estimasi.

a. R-Square $\left(R^{2}\right)$

Tabel 2.

Nilai $\mathrm{R}^{2}$ Variabel Endogen

\begin{tabular}{clcc}
\hline No. & \multicolumn{1}{c}{ Variabel } & $R$ Square & $R$ Square Adjusted \\
\hline 1 & Kecerdasan Emosional & 0.404 & 0.393 \\
\hline 2 & Kemandirian Belajar & 0.661 & 0.651 \\
\hline
\end{tabular}

Berdasarkan tabel dapat disimpulkan bahwa pengaruh pengasuhan orang tua dan kepercayaan diri terhadap kecerdasan emosional memberikan nilai sebesar 0.404 , yang dapat diinterprestasikan bahwa variabilitas kecerdasan emosional yang dapat dijelaskan oleh variabilitas pengasuhan orang tua dan kepercayaan diri berkontribusi sebesar $40.4 \%$ sedangkan sisanya dijelaskan oleh variabel lain diluar penelitian ini. Begitu juga dengan model pengaruh pengasuhan orang tua, kepercayaan diri dan kecerdasan emosional terhadap kemandirian belajar memberikan nilai sebesar 0.661, yang dapat diinterprestasikan bahwa variabilitas konstruk kemandirian belajar yang dapat dijelaskan oleh variabilitas konstruk pengasuhan orang tua, kepercayaan diri dan kecerdasan emosional berkontribusi sebesar 66.1\%, sedangkan sisanya dijelaskan oleh variabel variabel diluar penelitian ini.

\section{b. Uji Hipotesis}

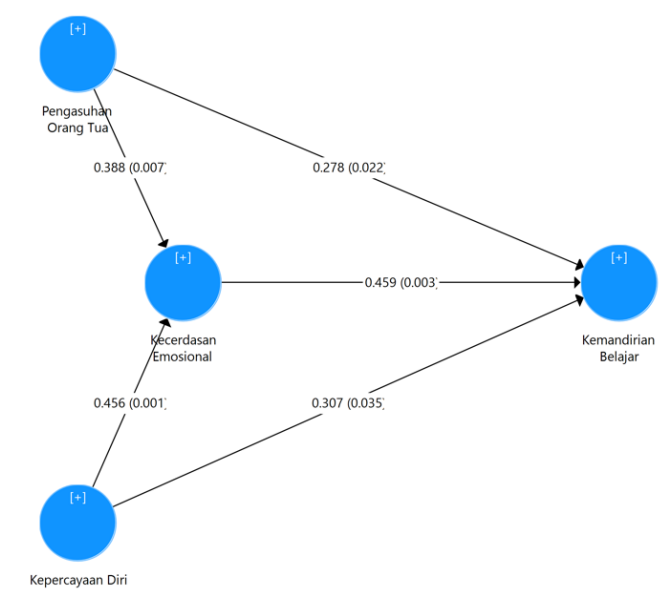

Gambar 1

Pengujian Model Struktural 
Untuk mengetahui pengaruh antar variabel, dilakukan metode bootsrapping. Pendekatan bootsrapp merepresentasi nonparametrik untuk precision dari estimasi. Dalam metode PLS, pengambilan keputusan untuk menerima ataupun menolak sebuah hipotesis didasarkan pada nilai signifikansi (P Value), dan nilai T - table. Dalam aplikasi SmartPLS, nilai signifikansi bisa diketahui dengan melihat nilai koefisien parameter dan nilai signifikansi t statistik. Kriteria penerimaan atau penolakan hipotesis adalah jika nilai signifikansi $\mathrm{t}$ - value $>1.96$ dan atau nilai $\mathrm{p}$ - value $<0.05$ pada taraf signifikansi $5 \%(\alpha$ 5\%) maka Ha diterima dan Ho ditolak, sebaliknya jika nilai t-value $<1.96$ dan atau nilai pvalue $>0.05$ pada taraf signifikansi 5\% ( $\alpha$ 5\%) maka Ha ditolak dan Ho diterima. Berikut hipotesis - hipotesis yang diajukan dalam penelitian ini:

Tabel 3.

Path Coefficient langsung

\begin{tabular}{lccccc}
\hline \multicolumn{1}{c}{ Jalur } & $\begin{array}{c}\text { Original } \\
\text { Sample (O) }\end{array}$ & $\begin{array}{c}\text { Sample } \\
\text { Mean (M) }\end{array}$ & $\begin{array}{c}\text { Standard } \\
\text { Deviation } \\
\text { (STDEV) }\end{array}$ & $\begin{array}{c}\text { T Statistics } \\
\text { (O/STDEV) }\end{array}$ & P Values \\
\hline $\begin{array}{l}\text { Kecerdasan Emosional - } \\
\text { > Kemandirian Belajar }\end{array}$ & 0.459 & 0.449 & 0.151 & 3.034 & 0.003 \\
\hline $\begin{array}{l}\text { Kepercayaan Diri -> } \\
\text { Kemandirian Belajar }\end{array}$ & 0.307 & 0.308 & 0.145 & 2.113 & 0.035 \\
\hline $\begin{array}{l}\text { Pengasuhan Orang Tua - } \\
>\text { Kemandirian Belajar }\end{array}$ & 0.278 & 0.294 & 0.121 & 2.293 & 0.022 \\
\hline
\end{tabular}

Konstruk pengasuhan orang tua mempunyai pengaruh positif yang signifikan $(0=$ 0.278) dengan kemandirian belajar. nilai $t$ - statistik pada hubungan konstruk ini adalah $2.293>1.96$, dan nilai $\mathrm{p}$ - value $0.022>0.05$. Oleh karena itu, hipotesis pertama yang menyatakan bahwa ada pengaruh pengasuhan orang tua terhadap kemandirian belajar terbukti.

Konstruk kepercayaan diri mempunyai pengaruh positif yang signifikan $(\mathrm{O}=0.307)$ dengan kemandirian belajar. nilai $\mathrm{t}$ - statistik pada hubungan konstruk ini adalah $2.113>$ 1.96 , dan nilai $\mathrm{p}$ - value $0.035 \mathrm{z}<0.05$. Oleh karena itu, hipotesis kedua yang menyatakan bahwa ada pengaruh kepercayaan diri terhadap kemandirian belajar terbukti.

Konstruk kecerdasan emosional mempunyai pengaruh positif yang signifikan $(0=$ 0.459 ) dengan kemandirian belajar. Nwxilai $t$ - statistik pada hubungan konstruk ini adalah $3.034>1.96$, dan nilai p - value $0.001>0.05$. Oleh karena itu, hipotesis ketiga yang menyatakan bahwa ada pengaruh kecerdasan emosional terhadap kemandirian belajar terbukti.

Terdapat pengaruh yang positif dan signifikan antara pengasuhan orang tua terhadap kemandirian belajar melalui kecerdasan emosional. Hal ini sesuai dengan hasil 
path coefficients dengan nilai original sampel 0.178 yang menunjukkan angka positif dengan nilai t-statistik 2.087 lebih besar dari 1,66 dan p-value 0,037 $(0.037<0,05)$.

Terdapat pengaruh yang positif dan signifikan antara kepercayaan diri terhadap kemandirian belajar melalui kecerdasan emosional. Hal ini sesuai dengan hasil path coefficients dengan nilai original sampel 0.209 yang menunjukkan angka positif dengan nilai t-statistik 2.163 lebih besar dari 1,66 dan p-value 0,031 $(0.031<0,05)$.

Tabel 4.

Rangkuman Hasil Uji Hipotesis

\begin{tabular}{clcc}
\hline No & \multicolumn{1}{c}{ Hipotesis } & T Statistik & Ket \\
\hline 1 & $\begin{array}{l}\text { Ada pengaruh pengasuhan orang tua terhadap kemandirian } \\
\text { belajar. }\end{array}$ & 2.293 & Terbukti \\
\hline 2 & $\begin{array}{l}\text { Ada pengaruh kepercayaan diri terhadap kemandirian } \\
\text { belajar. }\end{array}$ & 2.113 & Terbukti \\
\hline 3 & $\begin{array}{l}\text { Ada pengaruh kecerdasan emosional terhadap kemandirian } \\
\text { belajar. }\end{array}$ & 3.034 & Terbukti \\
\hline 4 & $\begin{array}{l}\text { Ada pengaruh pengasuhan orang tua terhadap kemandirian } \\
\text { belajar melalui kecerdasan emosional. }\end{array}$ & 2.087 & Terbukti \\
\hline 5 & $\begin{array}{l}\text { Ada pengaruh kepercayaan diri terhadap kemandirian } \\
\text { belajar melalui kecerdasan emosional. }\end{array}$ & 2.163 & Terbukti \\
\hline
\end{tabular}

\section{Simpulan}

Berdasarkan hasil penelitian dan analisis data yang telah dilakukan oleh peneliti, dapat diambil kesimpulan bahwa pengasuhan orang tua berpengaruh positif dan signifikan terhadap kemandirian belajar siswa. Kepercayaan diri berpengaruh positif dan signifikan terhadap kemandirian belajar siswa SMA. Kecerdasan emosional berpengaruh positif dan signifikan terhadap kemandirian belajar siswa SMA. Pengasuhan orang tua berpengaruh terhadap kemandirian belajar melalui kecerdasan emosional siswa SMA. Kepercayaan diri berpengaruh terhadap kemandirian belajar melalui kecerdasan emosional siswa SMA.

\section{Saran}

Hasil penelitian ini nantinya diharapkan dapat memberikan manfaat kepada pihakpihak terkait, antara lain bagi siswa dapat diketahui bahwa kemandirian belajar siswa perlu untuk ditingkatkan agar dapat mendapatkan hasil yang maksimal dalam setiap proses pembelajaran. Meningkatkan kemandirian belajar dengan cara lebih percaya diri saat mengerjakan tugas dan tepat waktu saat mengikuti pembelajaran. Bagi orang tua siswa dalam perkembangannya memerlukan kedekatan, keintiman dan kehangatan orang 
tua yang intensif. Adanya hal tersebut akan meningkatkan kepekaan sosialnya terhadap diri sendiri ataupun lingkungan sosial mereka sehingga dapat meningkatkan kemandirian belajar siswa. Bagi sekolah diharapkan guru mendampingi siswa-siswinya tidak hanya dalam materi pelajaran namun juga memberikan bimbingan dalam hal kepercayaan diri dan penerapan kecerdasan emosional sehingga dapat meningkatkan kemandirian belajar. Oleh karena itu pendampingan baik pengembangan intelektual ataupun emosional perlu dilakukan oleh bapak-ibu guru. Bagi peneliti selanjutnya penelitian ini diharapkan dapat menjadi acuan dan masukan atau referensi penelitian lain dengan topik tentang kemandirian belajar, kecerdasan emosional, pengasuhan orang tua, dan kepercayaan diri.

\section{Kepustakaan}

Afero, Baghdad \& Adman. (2016). Peran kecerdasan emosional sebagai faktor yang mempengaruhi kemandirian belajar siswa. Jurnal Pendidikan Manajemen Perkantoran, Vol. 1, No. 1, Agustus 2016.

Ali, Muhammad \& M. Asrori. (2018). Psikologi Remaja Perkembangan Peserta Didik. Jakarta: Bumi Aksara.

Alifiyarti, Tissa. (2019). Hubungan Antara Kecerdasan Emosi Dengan Kemandirian Belajar Siswa Kelas III Sd. Jurnal Pendidikan Guru Sekolah Dasar Edisi 4 Tahun Ke-8 Tahun 2019.

Ana, Yani Achdiani. (2015). Penerapan Self Regulated Learning Berbasis Internet Untuk Meningkatkan Kemandirian Belajar Mahasiswa. INVOTEC, Volume XI, No.1, Februari $2015: 15-22$.

Andayani, B., dan Koentjoro. (2012). Peran Ayah Menuju Coparenting. Laras: Taman Sidoarjo.

Apriandi, Rian Fitra. (2015). Pengaruh Kecerdasan Emosional, Kecerdasan Intelektual, Motivasi Terhadap Tingkat Pemahaman Akuntansi Dengan Kepercayaan Diri Sebagai Variabel Moderating. Indonesian Journal Of Educational Counseling. Volume 1, No. 2, Juli 2017: Page 145-162.

Asiyah, Nur. (2013) Pola Asuh Demokratis, Kepercayaan Diri dan Kemandirian Mahasiswa Baru. Persona, Jurnal Psikologi Indonesia. Mei 2013, Vol. 2, No. 2, hal 108 - 121.

Azwar, Saifuddin. (2016). Penyusunan Skala Psikologi. Yogyakarta :Pustaka Pelajar.

Brooks, Jane. (2011). The Process Of Parenting. Yogyakarta: Pustaka belajar.

Desmita. (2009). Psikologi Perkembangan. Bandung: PT. Remaja Rosdakarya.

Dewi, Ni Putu Ria Arista. Dkk (2016). Kepercayaan Diri Sebagai Pemoderasi Pengaruh Kecerdasan Emosional Dan Perilaku Belajar Pada Tingkat Pemahaman Akuntansi. EJurnal Akuntansi Universitas Udayana. Vol.16.1. Juli (2016): 615-644.

Dianah, Lili. (2017). Pengaruh Kecerdasan Emosional Dan Modal Sosial Terhadap Kemandirian Belajar Siswa Dalam Pembelajaran IPS. Social Science Education Journal, 4 (2), 2017, 13-20.

Elias, Maurice J, Dkk. (2002). Cara-Cara Efektif Mengasuh Anak Dengan EQ. Bandung: Kaifa.

Fitri Yulianto, H. Fuad Nashori. (2016). Kepercayaan Diri Dan Prestasi Atlet Tae Kwon Do Daerah Istimewa Yogyakarta. Jurnal Psikologi Universitas Diponegoro Vol.3 No. 1, Juni 2016.

Fitri, Emria. Nilma Zola. Ifdil Ifdil. (2018). Profil Kepercayaan Diri Remaja serta FaktorFaktor yang Mempengaruhi. Jurnal Pendidikan Indonesia. Volume 4 Nomor 1, 2018, hlm 1-5. 
Ghozali, I. \& Latan, H. (2015). Partial Least Squares: Konsep, Teknik dan Aplikasi Menggunakan Program SmartPLS 3.0. Semarang: Badan Penerbit Universitas Diponegoro.

Goleman, Daniel. (2001). Kecerdasan Emosional untuk Mencapai Puncak Prestasi (terjemahkan oleh Widodo). Jakarta: PT. Gramedia.

Gottman, John. Declaire, Joan. (2001). Kiat-Kiat Membesarkan Anak yang Memiliki Kecerdasan Emosional. Jakarta: Gramedia Pustaka Utama.

Haque, Ery Arofal. Rahmasari, Diana. (2013). Hubungan Antara Keterlibatan Ayah Dalam Pengasuhan Dan Kecerdasan Emosional Dengan Perilaku Prososial Pada Remaja. Jurnal Psikologi Indonesia. Mei 2013, Vol. 2, No. 2, hal 108 - 121.

Hidayati, Nur Istiqomah (2014) Pola Asuh Otoriter Orang Tua, Kecerdasan Emosi,Dan Kemandirian Anak SD. Persona, Jurnal Psikologi Indonesia. Januari 2014, Vol.3, No.01, hal1-8

Karlinawati, karlinawati. (2015). Hubungan Antara Kecerdasan Emosional Dengan Sikap Percaya Diri Siswa Di Kelas Vi Sekolah Dasar. Didaktika Tauhidi ISSN 2442-4544 Volume 2 Nomor 2, Oktober 2015.

Lauser, Peter. (2005). Tes Kepribadian. Jakarta: Bumi Aksara.

Listia Fitriyani, Listia. (2015). Peran Pola Asuh Orang Tua Dalam Mengembangkan Kecerdasan Emosi Anak. Lentera, Vol. XVIII, No. 1, Juni 2015.

Merona, Senja Putri. (2019). Penggunaan Modul Statistika Matematika Untuk Meningkatkan Kemandirian Belajar Mahasiswa Prodi Pendidikan Matematika FKIP Universitas Muhammadiyah Ponorogo. Jurnal Dimensi Pendidikan dan Pembelajaran. Vol 7 No 1 Januari 2019.

Mulyawati, Yuli \& Citra Christine (2019) Pengaruh Pola Asuh Orang Tua Terhadap Kemandirian Belajar Siswa. Jurnal Pendidikan \& Pengajaran Guru Sekolah Dasar Volume 02, Nomor 01, Maret 2019, Hal. 21 - 25.

Papalia, D. E., Old s, S. W., \& Feldman, R. D. (2009). Human Development Perkembangan Manusia. Jakarta: Salemba Humanika.

Pratiwi, Hermien. (2016). Kepercayaan Diri dan Kemandirian Belajar Pada Siswa SMA Negeri "X". Jurnal Psikologi Teori dan Terapan. 2016, Vol.7, No. 1, 43-49.

Pravitasari, dkk. (2019) Pola Pengasuhan Dan Internalisasi Nilai Kemandirian Anak Pada Wanita Karir Di Desa Tembokrejo Kecamatan Gumukmas Kabupaten Jember. Jurnal Pendidikan Ekonomi: Jurnal Ilmiah Ilmu Pendidikan, Ilmu Ekonomi, dan Ilmu Sosial. Volume 13 Nomor 1 (2019).

Ramadhan, Munggarani \& Ipah, Saripah (2017) Profil Kemandirian Siswa Sma Berdasarkan Urutan Kelahiran Dan Implikasinya Terhadap Bimbingan Dan Konseling. Indonesian Journal Of Educational Counseling. Volume 1, No. 2, Juli 2017: Page 145-162

Rozana, dkk. (2016). Studi Korelasi Pola Asuh, Religiusitas dengan Impulse Buying pada Mahasiswa Universitas Islam Bandung. Psympathic : Jurnal Ilmiah Psikologi Volume 3, Nomor 2, 2016: 235-248.

Sa'diyah, Rika. Pentingnya Melatih Kemandirian Anak. Kordinat Vol. Xvi No. 1 April 2017.

Shapiro. (2001). Mengajarkan Emotional Intelligence Pada Anak. Jakarta: Gramedia Pustaka Utama.

Sugiarti, Rini. Dkk (2021). Model Of Character Building For Junior High School Students In Semarang. Psychology And Education (2021) 58(3): 3558-3570.

Sugiyono.(2016).Metode Penelitian Kuantitatif,Kualitatif,dan R\&D. Bandung: Alfabeta.

Sujana, I.W.C. (2019). Fungsi Dan Tujuan Pendidikan Indonesia Adi Widya: Jurnal Pendidikan Dasar Volume. 4, Nomor 1 April 2019.

Sunarto. Agung Hartono. (2002) Perkembangan Peserta Didik. Jakarta: PT Rineka Cipta.

Sunarty, Kustiah. (2016). Hubungan Pola Asuh Orangtua Dan Kemandirian Anak. Journal of EST, Volume 2, Nomor 3 Desember 2016 hal 152-160. 
Suryabrata,S. (2014).Metodologi Penelitian.Jakarta:Rajawali Pers.

Syam, Asrullah \& Amri. (2017). Pengaruh Kepercayaan Diri (Self Confidence) Berbasis Kaderisasi Imm Terhadap Prestasi Belajar Mahasiswa. Jurnal Biotek Volume 5 Nomor 1 Juni 2017.

Tasaik, Hendrik Lempe. Patma Tuasikal. (2018). Peran Guru Dalam Meningkatkan Kemandirian Belajar Peserta Didik Kelas V Sd Inpres Samberpasi. Metodik Didaktik: Vol. 14 No. 1, Juli 2018, Hal 45-55.

Upadhyay, Dheeraj. Dkk. (2020). Self-Confidence A Demeanor To Emotional Intelligence. Proteus Journal. Volume 11 Issue 11 2020. http://www.proteusresearch.org/

Wiswanti, Inge. Dkk. (2020). Pola Asuh Dan Budaya: Studi Komparatif Antara Masyarakat Urban Dan Masyarakat Rural Indonesia. Jurnal Psikologi Sosial 2020, Vol. 18. No. 03, 211-223.

Yuliati, Yuyu. Saputra, Dudu Suhandi (2020). Membangun Kemandirian Belajar Mahasiswa Melalui Blended Learning Di Masa Pandemi Covid-19. Jurnal Elementaria Edukasia. Volume 3 No 1 Tahun 2020.

Zahara, Fenty (2017) Pengendalian Emosi Ditinjau Dari Pola Asuh Orangtua Pada Siswa Usia Remaja Di Sma Utama Medan. Kognisi Jurnal, Vol.1 No.2. 